\title{
DYSKUSJA
}

Klio. Czasopismo poświęcone dziejom Polski i powszechnym

PL ISSN 1643-8191, t. 26 (3)/2013, s. 209-235

\author{
(i) $\ominus$ \\ DOI: http://dx.doi.org/10.12775/KLIO.2013.038

\section{Debata „Dzień dzisiejszy i perspektywy dydaktyki historii w Polsce na tle europejskim"}

W Instytucie Historycznym Uniwersytetu Wrocławskiego 23 stycznia 2013 r. odbyła się sesja naukowa związana z jubileuszem czterdziestolecia Zakładu Dydaktyki Historii i Wiedzy o Społeczeństwie IH UWr, połączona z promocją księgi jubileuszowej, dedykowanej Pani Profesor Grażynie Pańko, obecnemu kierownikowi tego Zakładu, a pracownikowi od samego początku jego istnienia. Sesję rozpoczęła dwuipółgodzinna debata na temat „Dzień dzisiejszy i perspektywy dydaktyki historii w Polsce na tle europejskim", której autoryzowane streszczenie znajduje się poniżej.

\section{Wrowadzenie: Joanna Wojdon (Uniwersytet Wrocławski)}

Badania prowadzone w ramach projektu LLP-Erasmus „Ocenianie, struktury kształcenia i wstępne przygotowanie do zawodu nauczyciela studentów przedmiotów kształcenia politycznego i obywatelskiego, nauk o społeczeństwie i kulturze oraz studentów historii w Europie - studium porównawcze", kierowanego przez prof. Aloisa Eckerta z Uniwersytetu Wiedeńskiego, przynoszą dość optymistyczne dane, jeśli chodzi o perspektywy rozwoju dydaktyki historii i perspektywy kształcenia nauczycieli w Europie. Okazuje 
się bowiem, że w roku akademickim 2008/2009 w 47 krajach Europy było ponad $40 \mathrm{mln}$ studentów, z których ponad 3,3 mln kształciło się na nauczycieli, a ponad 500 tys. - na nauczycieli przedmiotów historycznych i społecznych oraz geografii. Kolejne wyniki wskazują, że wiek obecnych nauczycieli w Europie jest dość zaawansowany i ponad 50\% z nich przejdzie na emeryturę w ciaggu 10-12 lat. To i szansa, i wyzwanie dla osób zajmujących się kształceniem nowych nauczycieli. Rodzi się pytanie: jacy będą ci nowi nauczyciele? Z jakich środowisk politycznych, kulturalnych, społecznych będą się wywodzić? Jakiej historii będą uczyć? Jakie wartości przekazywać? Jakimi umiejętnościami dysponować? Pewien wpływ na to mają dydaktycy, którzy ich do tego fachu przygotowują. Przygotowanie to w Europie ma miejsce głównie na uniwersytetach, cieszących się - w zależności od kraju - większą lub mniejszą autonomią w zakresie programów kształcenia nauczycieli. Mam wrażenie, że w Polsce autonomia ta zmniejsza się ostatnio, rośnie natomiast rola (i objętość) odgórnych, ministerialnych wytycznych.

Te same, koordynowane przez Wiedeń, badania zajmują się także treściami przekazywanymi w toku kształcenia nauczycielskiego w różnych krajach Europy. Nasuwają się tu następujące spostrzeżenia:

1. W większości krajów absolwenci historii uczą także pozostałych przedmiotów społecznych: wiedzy o społeczeństwie, wychowania obywatelskiego, wiedzy o kulturze.

2. Około 20\% czasu studiów poświęca się na zajęcia z przygotowania pedagogicznego i ten udział ma tendencję wzrostową.

3. Zajęcia z dydaktyki przedmiotowej są odizolowane od zajęć kształcenia historycznego. Wielką rzadkością są np. zajęcia zintegrowane, współprowadzone przez specjalistów z historii i z dydaktyki.

4. Bardzo rzadko dydaktyka przedmiotowa odwołuje się do jakichś założeń/koncepcji teoretycznych, naukowych.

5. Często dydaktyka nie jest doceniana jako dyscyplina naukowa, a osoby, które pragną rozwijać karierę akademicką, „przenoszą się” do innych obszarów: historii, pedagogiki.

6. Jeśli chodzi o treści zajęć z dydaktyki przedmiotowej, nieźle wygląda w Europie przygotowanie do uczenia aktywizującego skoncentrowanego na uczniu, do kształcenia umiejętności. Mniejszą 
wagę przywiązuje się do wdrażania do nauczania podającego. W dobrym kierunku rozwija się też przygotowanie do wykorzystania zróżnicowanych środków dydaktycznych, w tym TI - choć tu sytuacja przedstawia się nieco słabiej. Nie najlepiej jednak sprawa ma się z wdrażaniem różnych form oceniania i udzielania informacji zwrotnej. Dość słabo - do kształcenia metodą projektu czy do przygotowywania portfolio. Marnie - do współpracy interdyscyplinarnej w nauczaniu historii. Wręcz fatalnie - do pracy zespołowej i Web 2.0 czy do produkcji pomocy audiowizualnych (CD, video, filmy, strony internetowe).

7. Niewiele miejsca poświęca się też takim sprawom jak wielokulturowość w nauczaniu historii, dialog międzykulturowy, zrozumienie dla różnorodności. I to mimo że te właśnie zagadnienia są ostatnio przedmiotem zainteresowania dydaktyki jako nauki. Spośród konferencji Międzynarodowego Stowarzyszenia Dydaktyki Historii w ostatnich 10 latach można przytoczyć: dialog międzykulturowy, obraz „obcego” w nauczaniu historii, zróżnicowanie kulturalne i religijne oraz jego implikacje dla nauczania historii.

8. Inne aspekty poruszane podczas tych konferencji to: kolonializm, dekolonizacja i postkolonializm, nauczanie historii światowej (prawdziwie powszechnej), świadomość historyczna, publiczne użytki historii, relacje między wychowaniem obywatelskim/wiedzą o społeczeństwie a historią szkolną.

9.Zajmowano się także kwestiami metodologicznymi, takimi jak: badania empiryczne nad nauczaniem historii, problemy metodologiczne analizy podręczników do historii, badania naukowe nad historią szkolną.

W Polsce w bazie OPI znalazłam 73 osoby, które mają wpisaną „dydaktykę historii" jako swoją specjalność naukową, w tym 29 o stopniu co najmniej doktora habilitowanego. Pewnym mankamentem tej bazy jest fakt, że uwzględnia ona zarówno badaczy żyjących, jak i zmarłych. Często oprócz dydaktyki historii osoby te mają wpisaną także inną specjalność, najczęściej związaną z jakąś epoką historyczną. I to jest - wydaje mi się spora słabość naszej (i nie tylko naszej - w Europie jest podobnie) dydaktyki historii. Jest traktowana jako dodatek, poboczne zainteresowanie. Brakuje 
nam prawdziwych badań z tej dziedziny. Jeśli przyjrzymy się naszym referatom na konferencjach naukowych, to bardzo często dotyczą one historii oświaty albo są analizą dokumentów programowych, podręczników, środków dydaktycznych - w różnych aspektach, ale to najczęściej subiektywne odczucia recenzenta/referenta. Albo przedstawiamy pomysły rozwiązań metodycznych, ale właśnie pomysły, niezweryfikowane w praktyce szkolnej. Brakuje prawdziwych badań pedagogicznych, eksperymentów, które pokazywałyby skuteczność proponowanych metod, technik, rozwiązań. Brakuje otwarcia na współpracę z pedagogami i z osobami spoza naszego grona. Dobrze, że jesteśmy dość zintegrowani, że odbywa się kilka cyklów regularnych konferencji, do tego konferencje „okazjonalne”, najczęściej kończące się publikacjami. Mamy „Wiadomości Historyczne” i jeden numer „Klio” co roku. Ale wydaje mi się, że brakuje wspólnych działań, poważnych badań, dyskusji o charakterze naukowym (w tym polemik, krytycznych recenzji), projektów badawczych (nie tylko dydaktycznych). Wydaje mi się, że warto byłoby zastanowić się nad wytyczeniem potencjalnych wspólnych obszarów badawczych oraz nad ich możliwymi ramami organizacyjnymi.

Wydaje mi się także, że konieczne jest nasze większe otwarcie na kontakty międzynarodowe, na współpracę z badaczami z innych krajów, na recepcję ich osiągnięć (i ich uwzględnianie w naszych publikacjach), ale też szerszą prezentację naszych. Nie powinno być tak, że na konferencjach międzynarodowych przedstawicieli Niemiec jest kilkunastu, Szwajcarii, Szwecji, Finlandii, a nawet Estonii - kilku, a z Polski - nie ma nikogo.

\section{Grażyna Pańko (Uniwersytet Wrocławski)}

W zajęciach akademickich ważna jest interdyscyplinarność w kształceniu nauczycieli i korelacja międzyprzedmiotowa. Wśród nauczycieli szkół ponadgimnazjalnych słyszy się opinię o małej wiedzy i umiejętnościach absolwentów gimnazjów. Nie można uogólniać, bo są i świetni uczniowie, ale warto zauważyć, że błędem było założenie, że w szkole podstawowej ważne jest pokazanie ogólne rozwoju dziejów (perspektywy) i kształtowanie umiejętności podstawowych. To zasugerowało, że wiedza jest mniej ważna. Gimnazjum jest tym typem szkoły, w której uczniowie powinni 
zdobyć konkretną, uporządkowaną wiedzę. Ponadto trzeba tam ćwiczyć umiejętności. Problem stanowi fakt, że gimnazjaliści nie przykładają się do zdobywania wiedzy. Konieczne jest więc zainteresowanie młodzieży zdobywaniem wiedzy i jej utrwalaniem.

\section{Barbara Kubis (Uniwersytet Opolski)}

Mówiąc o związkach polskiej dydaktyki historii z europejska, warto przypomnieć kilka kwestii.

Po pierwsze, pojęcie dydaktyki historii jako dyscypliny akademickiej, wywodzącej się z nauk historycznych - zwłaszcza w tradycji niemieckiej. Cytując słowa prof. Klausa Bergmanna z Giessen: „Dydaktyka historii rozważa możliwości przybliżenia człowiekowi adekwatnego wizerunku minionego czasu". Takie widzenie dominuje we Francji, Belgii, Holandii, Szwecji, Rosji, a także w Polsce. Po drugie, w kręgu kultury anglosaskiej dydaktyka ma raczej charakter instruktażowo-metodyczny i jest lokowana wśród nauk pedagogicznych, a nie historycznych. Podstawą opracowania metodycznego są tam standardy edukacyjne, z którymi trzeba się liczyć.

Obie te tendencje widoczne są $\mathrm{w}$ pracach Międzynarodowego Stowarzyszenia Dydaktyki Historii, wśród członków którego są przedstawiciele Polski. Zwłaszcza interesujący jest temat konferencji w $2013 \mathrm{r}$. w Tutzing w Bawarii, który brzmi: „Kolonializm, dekolonizacja i postkolonialne perspektywy historyczne - wyzwania dla dydaktyki historii i nauczania historii w globalizującym się świecie".

W polskich badaniach dydaktycznych brak obecnie stabilności, współpracy z różnymi instytucjami oświatowymi, w tym zagranicznymi. Brakuje także planu i celu badań. Zerwaliśmy z ciekawymi badaniami lat wcześniejszych, a te, które są, najczęściej ograniczają się do regionu. Brakuje koordynacji i wiodących instytucji. 


\section{Teresa Maresz (Uniwersytet Kazimierza Wielkiego w Bydgoszczy)}

Zastanawiając się, jak kształcić przyszłych nauczycieli, pragnę zwrócić uwagę na dwa aspekty.

Po pierwsze, należy ich kształcić wieloprzedmiotowo. Po drugiej wojnie światowej taki model był podyktowany koniecznością - nie dość liczną kadrą nauczycielską. Obecnie dwuprzedmiotowość zwiększa szansę absolwentów na znalezienie pracy. Rzeczywiście, najczęściej historia jest łączona z wiedzą o społeczeństwie, ale zdarzają się także mariaże bardziej egzotyczne: sama znam nauczycielkę fizyki, zdobywającą uprawnienia do nauczania wiedzy o społeczeństwie, by uzupełnić etat.

Po drugie, ważne, by zachować dydaktykę historii w instytutach historycznych. Jeszcze w PRL zarysowała się tendencja, by ją stamtąd wyprowadzić, związać ją silniej z pedagogiką, w oderwaniu od przygotowania merytorycznego. Także w obecnym programie studiów w zakresie przygotowania do zawodu nauczyciela jest sporo godzin ogólnego przygotowania pedagogicznego - pedagogiki, psychologii - a dydaktyka przedmiotowa jest traktowana jedynie jako dodatek. Pojawia się problem zapewnienia wysokiej jakości przygotowania dydaktycznego. Szczęśliwie mądre ośrodki, takie jak Wrocław, Opole, Katowice, Poznań, Zielona Góra, Bydgoszcz, usilnie starały się zachować dydaktykę w instytutach historii. Dzisiaj stoi przed nimi nowe wyzwanie: by zainteresować studentów przygotowaniem nauczycielskim. W okresie powojennym takim przygotowaniem byli objęci wszyscy studenci historii, niezależnie od tego, jak planowali swoją przyszłość. Dziś jest to kwestia wyboru samych studentów, a naszym zadaniem jest umiejętne przekonanie ich o tym, że warto nabyć uprawnienia zawodowe. Obawiam się, że przy małej liczbie chętnych otwieranie grup pedagogicznych może okazać się dla władz uczelni nieopłacalne (i zajęcia z dydaktyki zanikna). W świetle przytaczanych wcześniej danych statystycznych, ale i moich osobistych doświadczeń, nie jest to, moim zdaniem, kształcenie bezrobotnych. Nasi absolwenci prędzej czy później znajdują pracę w zawodzie, a zwłaszcza wtedy, jeśli potrafią się wykazać przygotowaniem do nauczania dwóch przedmiotów.

W nawiązaniu do wypowiedzi moich poprzedniczek apeluję do Pani Zofii Kozłowskiej, aby kontynuować spotkania dydaktyków historii, zaini- 
cjowane w styczniu 2012 r., gdy dyskutowaliśmy na spotkaniach Polskiego Towarzystwa Historycznego o efektach kształcenia z zakresu dydaktyki historii w ramach Krajowych Ram Kwalifikacji. Niech planowane kolejne zebrania Komisji Dydaktyki przy PTH nie będą miały charakteru wielotematycznego, ale zostaną poświęcone w większym stopniu kształceniu przygotowującemu do wykonywania zawodu, zwłaszcza dla dobra przyszłych nauczycieli.

\section{Bohdan Halczak (Uniwersytet Zielonogórski)}

Praca nauczyciela staje się coraz trudniejsza, nauczyciel musi potrafić sprostać coraz większym wymaganiom.

Przyjrzyjmy się nauczycielom akademickim. Kiedyś, by przeprowadzić wykład, wystarczyło go wygłosić w sposób mniej lub bardziej zrozumiały. Dziś studenci domagają się nie tylko, by było zrozumiale, ale także np., by użyć różnych środków wizualnych. To jedna grupa wyzwań, przed którymi stają wykładowcy.

Druga wiąże się z samymi studentami. Kiedyś była ostra selekcja kandydatów na studia, a osoby niespełniające wymogów łatwo ze studiów usuwano. Dzisiaj sytuacja wygląda zupełnie inaczej. Efektem jest to, że na wyższych studiach pojawiają się problemy, niegdyś spotykane w szkołach średnich, zawodowych czy nawet w ostatnich klasach szkoły podstawowej. Kadra akademicka starszego pokolenia raczej potrafi sobie z nimi poradzić, bo wszyscy z nas mają za sobą przygotowanie pedagogiczne, a często wręcz uczyli w szkole. Ale młodsi koledzy przeżywają stres, konflikty ze studentami, zatargi. Czy to źle, że następuje upowszechnienie nauczania akademickiego? Uważam, że dobrze. Ale stawia to przed nauczycielami akademickimi nowe wymagania. Ze studentami trzeba teraz postępować tak, jak kiedyś się postępowało z uczniami w szkole średniej. Nauczyciel akademicki musi być także wychowawcą. Tymczasem kandydaci na nauczycieli akademickich są do tego zupełnie nieprzygotowani. Posiadają niezłą wiedzę akademicką, ale wiedzę pedagogiczną, dydaktyczną - czasami żadną. Jeśli chodzi o Uniwersytet Zielonogórski, to tutaj dzięki staraniom Profesor Bogumiły Burdy w ramach studiów doktoranckich zostały wprowadzone - nie bez oporów - zajęcia z dydaktyki szkoły wyższej. 
Także na niższych szczeblach edukacji wymagania wobec nauczycieli są coraz wyższe. Tymczasem jak się kształci nauczycieli? Wydaje się, że poświęca się temu coraz mniej uwagi. Niestety spada także liczba instytucji do dyspozycji nauczyciela, a samo przygotowanie nauczyciela jest traktowane coraz bardziej po macoszemu. Dotyczy to także nauczycieli historii. W instytutach historycznych można zaobserwować dążenie do wyprowadzenia dydaktyki poza instytut. Dlaczego? Jest to element ogólnej tendencji w Polsce po 1990 r.: w ramach cięcia kosztów likwiduje się bardzo wiele rzeczy. Ponadto mamy konkurencję: pedagogów, którzy chcieliby przywłaszczyć całe przygotowanie pedagogiczne. O ile jednak mają oni wiedzę pedagogiczną, o tyle z dydaktykami szczegółowymi sobie nie poradzą. Mamy też konkurencję w postaci polityków, którzy najchętniej także zawłaszczyliby dydaktykę historii. Czym bowiem innym jest tzw. polityka historyczna, jeśli nie dydaktyką historii w wykonaniu polityków. Jest to bardzo niebezpieczne. Polityka preferuje bowiem pewnych ludzi, ludzi o mentalności sportowca, dla których najważniejsza jest wygrana. Nie myślą o celach dalszych. Oddawanie politykom dydaktyki historii jest bardzo niebezpieczne. Tym bardziej że główne podziały polityczne w naszym kraju opierają się na sporach historycznych: o PRL, o katastrofę smoleńską i kilka innych jeszcze kwestii historycznych. Politycy te podziały chcą jątrzyć, pogłębiać. Tymczasem profesjonalny dydaktyk starałby się raczej te podziały łagodzić, wyjaśniać.

\section{Anna Glimos-Nadgórska (Uniwersytet Śląski w Katowicach)}

Chciałabym poruszyć dwie kwestie, które zostały już po części podniesione, dotyczące oceny kształcenia nauczycieli przez media, przez społeczeństwo. Pracuję już prawie 40 lat, dzieci naszych absolwentów przychodzą już na studia. I przez cały czas mówi się o tym, że w Polsce jest zły system kształcenia nauczycieli. Ale nasi absolwenci mówią, że są dobrymi nauczycielami, że dobrze ich nauczyliśmy. Sama też mam rozeznanie, jak kiedyś wyglądało przygotowanie pedagogiczne, bo skończyłam liceum pedagogiczne. Dlaczego więc media twierdzą, że system jest zły? Chciałabym zwrócić uwagę na dwa aspekty. 
Pierwszą kwestią jest, od lat zaniedbywany, także ze względu na koszty, kontakt teorii z praktyką. Zajęcia praktyczne studentów są coraz bardziej zaniedbywane. Kiedyś były obowiązkowe praktyki śródroczne. Przed podjęciem nauczania w szkole każdy student musiał przeprowadzić jedną lekcję próbną. Dziś już tego nie ma, a przynajmniej nie we wszystkich ośrodkach. W nowym rozporządzeniu pojawiło się natomiast wiele obowiązkowych treści, które należy poruszyć podczas przygotowania pedagogicznego. W efekcie jednak zabraknie czasu na te zagadnienia, które kiedyś były omawiane, bo w nowym kanonie się nie mieszczą. Zabraknie też czasu na gruntowne przepracowanie spraw podstawowych, takich jak prowadzenie lekcji, pisanie konspektu, stosowanie podstawowych środków dydaktycznych, czy metod nauczania. Autonomia w zakresie doboru treści przez doświadczonych przecież dydaktyków zawsze była istotna.

Praktyki zaś są istotnym elementem formowania przyszłego nauczyciela. Studentom brakuje kontaktu z uczniem. Nie da się teoretycznie omówić wszystkich sytuacji, z którymi spotka się nauczyciel w szkole. To praktyka stwarza okazję, by student próbował sobie z takimi sytuacjami radzić i uczył się je rozwiązywać.

Aby osiagać w tym zakresie sukces, istotna zawsze była i jest podbudowa psychologiczno-pedagogiczna. I to druga kwestia, którą chciałabym poruszyć - problem integracji między dydaktyką a pedagogiką i psychologią, która powinna mieć miejsce, a której brakuje. Staram się o tę integrację, o współpracę z osobami, które te zajęcia prowadzą, ale muszę przyznać, że dotąd te starania spełzły na niczym. Kiedyś bywało tak, że władze różnego szczebla - instytutowe, dziekańskie, rektorskie - sprzyjały takiej integracji i korelacji, bo i możliwości były nieco większe. Dzisiaj - bez wsparcia tych władz, bez działań w tym kierunku - efekt jest taki, że gdy przechodzimy do zagadnień dydaktyki historii, okazuje się, że studentom brakuje przygotowania z pedagogiki i dydaktyki ogólnej. Zajmują się psychologią wieku niemowlęcego, historią wychowania, historią szkolnictwa, ale nie znają np. zasad budowy lekcji czy tworzenia konspektu.

To nie system kształcenia nauczycieli jest zły, ale wspomniane dwa jego elementy wymagają zmian. I jeszcze jedna uwaga: kiedyś praktyki pedagogiczne odbywały się w czasie wakacji. Studenci trochę narzekali, ale praktyki nie kolidowały ani z pracą szkoły, ani z zajęciami studentów. Dziś 
natomiast w strukturę trzyletnich studiów licencjackich bardzo trudno te praktyki pedagogiczne wpisać tak, by równocześnie studenci nie mieli zajęć na uczelni, a sprawę dodatkowo komplikują ruchome terminy ferii szkolnych i brak ich korelacji z sesją na uczelni.

\section{Adam Suchoński (Uniwersytet Opolski)}

Europejski Wymiar Edukacji Historycznej został zapoczątkowany tzw. Deklaracją Wiedeńską z października 1993 r., podpisaną m.in. innymi przez premier Hannę Suchocką. Powołano wówczas zespół ekspertów, który miał przygotować pewne ogóle trendy, tendencje - bez narzucania niczego nikomu - jakie powinny dominować w Europie w sytuacji, kiedy kontynent integruje się, by edukacja historyczna mogła być pomocna w tym zakresie. Jak pokazuje bowiem np. sytuacja na Półwyspie Bałkańskim, edukacja historyczna może być wykorzystywana do przypominania konfliktów, budzenia nienawiści do sąsiada - tak jak jeden z podręczników z RPA, promujący czarny rasizm, gdzie każda lekcja jest kończona tzw. odzewem wychowawczym: „najwyższy czas, by wypędzić białych z naszego kraju”.

Od 1997 r. zaczęły się coroczne spotkania ekspertów EWEH. Na żadnym z tych spotkań nie był obecny przedstawiciel Polski. Kiedy przygotowywano Światowy Kongres Nauk Historycznych w Oslo w 2000 r., Komitet Nauk Historycznych PAN zaproponował siedemnastoosobową delegację, której miałem być członkiem. Część dydaktyczna, mocno obsadzona i kierowana przez Profesora Karla Pellensa, miała dotyczyć świadomości historycznej, która może być kształtowana na trzech poziomach: regionalnym, narodowym i europejskim. Pod tym kątem miałem też przygotowane wystąpienie na przykładzie relacji polsko-niemieckich i polsko-rosyjskich. Dwa tygodnie przed wyjazdem przyszła decyzja: nie jechać, rzekomo z powodów finansowych. Dzięki pomocy, także finansowej, kolegów z zagranicy, zwłaszcza ze Szwecji, udało mi się tam być i w bogatym zbiorze materiałów opublikowanych po konferencji zamieścić swoją pracę. Po konferencji próbowałem zainteresować tym zagadnieniem Mirosława Sielatyckiego, który był w tym czasie szefem Centralnego Ośrodka Doskonalenia Nauczycieli. Przygotowaliśmy materiały do druku, ale minister Roman Giertych za- 
bronił ich dystrybucji. Polskie władze oświatowe stanęły na stanowisku, że Polska nie potrzebuje obcych wzorców, jak uczyć historii. I tekst wciąż się w Polsce nie ukazał, mimo moich licznych monitów. Odcięliśmy się od tego, co się nazywa Europejskim Wymiarem Edukacji Historycznej. Polscy ministrowie edukacji z rzadka pojawiają się na cyklicznych spotkaniach.

EWEH zaś się rozwijał. W 2002 r. ukonstytuował się zespół ekspertów pod kierunkiem Roberta Stradlinga, brytyjskiego historyka i dydaktyka, który opracował książkę pt. Crossroads of European Histories, wydaną w 2006 r. w Strasburgu. Na nic jednak wszelkiego rodzaju petycje do ministerstwa, by chociażby zamieszczony tam wstęp (o tym, jak radzić sobie w przypadku, gdy występują kontrowersje) opublikować w Polsce. Książka przeznaczona jest zaś dla autorów programów, podręczników, a także dla nauczycieli historii. Umożliwia ona umieszczenie regionalnej, narodowej, a także światowej historii w szerszym kontekście rozwijania wiedzy, dokonywania powiązań historycznych z perspektywy czasu i przestrzeni itd. A zatem nieprawdą i absurdem jest straszenie, że to zagraża naszej tożsamości. Raczej jest to przejaw tego, co zostało już podniesione w naszej dyskusji - upolitycznienia naszej edukacji historycznej. Dwukrotnie były podejmowane próby opracowania materiałów do nauczania historii krajów należących do Rady Europy oraz do UE. Byliśmy jedynym krajem, którego przedstawiciele zaprotestowali przeciwko takim materiałom, twierdząc, że to zmusi nas do ujednolicenia ocen, do przyjęcia poglądów innych. Tymczasem dzisiaj sytuacje kontrowersyjne, różne poglądy, przedstawia się w podręcznikach łącznie, bez wskazania, kto ma rację.

Odizolowana od tych tendencji europejskich, wadliwa jest nasza dzisiejsza podstawa programowa nauczania historii. Zwracali na to uwage m.in. członkowie sekcji poświęconej obrazowi Polski w zagranicznych podręcznikach do historii, której miałem zaszczyt przewodniczyć podczas ubiegłorocznego II Światowego Kongresu Badaczy Dziejów Polski z zagranicy.

Przy opracowywaniu podstawy nie uwzględniono kryteriów doboru materiału, wypracowanych w ramach EWEH: by uczyć tylko tych treści z historii, które pomogą lepiej zrozumieć współczesne problemy, które pokazują, czym jest historia; dzięki temu znalazłoby się miejsce na historię najnowszą w III klasie historii gimnazjalnej i nie byłoby wszystkich związanych z tym problemem „przepychanek”. 
To, co najbardziej boli, to brak racjonalnych sugestii, które pozwalałyby nawet ten wadliwy program zinterpretować i odczytać zgodnie ze współczesnymi wymogami. Tak, by młodzież wiedziała, po co uczy się historii, jakie są korzyści z tej edukacji historycznej. Tylko w naszych programach i podręcznikach nie ma fragmentów „Historyczne korzenie współczesnych procesów integracyjnych”. Powinno być hasło „Polscy ojcowie Europy”, czego się od dawna domagam. Przy okazji obchodów stopięćdziesięciolecia powstania styczniowego należałoby spopularyzować dwie postacie, które przemawiają do współczesności, do młodzieży. Stefan Bobrowski, 23 lata, wspaniały człowiek, utalentowany, zginął z polskiej ręki. I jeszcze rzadziej wzmiankowany w jubileuszowych publikacjach, które starannie śledzę, Stefan Buszczyński - postać klasyczna, która powinna znaleźć się we wszystkich podręcznikach. Był dowódcą jednego z lepiej funkcjonujących oddziałów powstańczych, a potem, gdy musiał się udać na emigrację, zamienił karabin na pióro i napisał książkę Upadek Europy w 1867 r., zawierając tam wizję czasów, w których żyjemy i przewidując dosyć dokładnie funkcjonowanie integracji europejskiej, a nawet nadmierną biurokrację wszystkich instytucji europejskich. Wizjoner, a równocześnie bohater. Brak takich postaci w edukacji historycznej powoduje, że historia nie jest przez młodzież rozumiana. Zajmuje się bowiem rzeczami, które nie mają przełożenia na współczesność.

Innym zagrożeniem edukacji historycznej, o którym była już mowa, jest upolitycznianie historii. Sprawa nie dotyczy jedynie okresu PRL. Całkiem niedawno ukazała się propagandowa publikacja IPN Od niepodlegtości do niepodlegtości, gdzie już na wstępie, na stronie 8 jest napisane, co należy ocenić pozytywnie, a co negatywnie. Przy czym na ocenę pozytywną nie zasługuje nic, co się działo w okresie PRL. Opracowanie IPN zostało podniesione do rangi podręcznika, przy biernej postawie środowiska historycznego.

Polityka historyczna przybiera monstrualne rozmiary. Powinniśmy wszyscy dołożyć starań, by edukacja historyczna nie była upolityczniona. Tymczasem to upolitycznienie dzieje się na naszych oczach. Te wszystkie protesty, głodówki, przywiązywanie się do słupów na rynku - ich uczestnicy nie bardzo wiedzieli, o co chodzi, zabiegając jedynie o popularność. Przez to stało się już to, co najgorsze - wejście polityki do edukacji histo- 
rycznej. Powinniśmy temu położyć tamę i przyjąć, że Europejski Wymiar Edukacji Historycznej nie stanowi zagrożenia dla naszej tożsamości. Nie musimy naśladować tego, co wypracowali inni, ale było to robione przez lata, przez zespoły ekspertów, przez badania, na które były wyłożone olbrzymie pieniądze. Tymczasem u nas takie badania wdrożeniowe, symulacyjne w ogóle nie wchodzą w grę - czego świadectwem jest nasza aktualna podstawa programowa.

\section{Zofia Kozłowska (Polskie Towarzystwo Historyczne)}

Motto mojego wystąpienia to odwołanie do wypowiedzi prof. Stefana Kieniewicza na XIV Powszechnym Zjeździe Historyków Polskich w Poznaniu w 1974 r. Rozpoczynając sympozjum „Etyka nauczyciela historii”, Profesor powiedział: „Sytuacja nauczyciela historii jest trudna. A kiedy była łatwa?”. Obecnie obowiązująca teoria i praktyka edukacji historycznej, zarówno na poziomie szkolnym, jak i uniwersyteckim, stawia nauczyciela historii w niezwykle trudnej sytuacji, o której chcę powiedzieć w kilku punktach.

1. Dyskutując o zakresie edukacji historycznej, lokuje się wybór treści między historią ojczystą a historią powszechną. W trosce o oszczędność czasu zabrakło w podstawie programowej światowego wymiaru historii, szczególne ważnego w dobie rozszerzającego się świata. Sądzę, że na naszym polskim gruncie warto też porozmawiać o myśleniu kolonialnym, nie tylko w odniesieniu do mniejszości narodowych w dłuższym wymiarze czasowym, ale też do przybywających do Polski imigrantów. Warto temu zagadnieniu poświecić odrębną konferencję. Podręczniki, które mają wspierać nauczyciela, są skracane w trosce o łatwość zbycia ze szkodą jednak dla ich zawartości, a recenzenci (także prasowi) nie zauważają różnicy między treścią podstawową a źródłem cytowanym dla kształcenia sprawności krytycznego myślenia u ucznia.

Warto tu dodać, że wspomniany w poprzednich wypowiedziach podręcznik wydawany przez IPN Od niepodlegtości do niepodlegtości tylko we fragmentach został zrecenzowany przez historyka spoza IPN, Jerzego Bracisiewicza, pozostali recenzenci to pracownicy Instytutu. Recenzja, 
którą przesłałam, nie doczekała się odpowiedzi, zaś na spotkaniu zorganizowanym w Towarzystwie Miłośników Historii autorzy twierdzili, że są obrońcami prawdziwej historii. Warto jednak dodać, że np. nie znalazła się tam nawet wzmianka o Marku Edelmanie. Dlaczego? Może lepiej nie snuć przypuszczeń. Ten obiektywny w opinii autorów podręcznik został bezpłatnie rozesłany do wszystkich szkół.

2. Struktura szkoły po reformie i podział podstawy programowej budzi żywą dyskusję. Istnieje propozycja przyjęcia rozwiązania łączącego w miarę możliwości gimnazja i licea w jedną całość. Propozycja takich korekt jest dyktowana troską o spójność w nauczaniu i wychowaniu szkolnym. Pogłębienie przygotowania nauczycieli do zadań wychowawczych w odniesieniu do przyszłych nauczycieli historii jest szczególnie ważne. Niedobrze się stało, że zostały ograniczone praktyki studenckie, a w ich omawianiu nie można zwracać stosownej uwagi na rozłożenie akcentów wychowawczych $\mathrm{w}$ toku lekcji, a zarazem w całym procesie edukacyjnym.

3. Wszystkie poruszone dzisiaj problemy są przedmiotem licznych konferencji organizowanych przez różne środowiska, jednak prawie zawsze brakuje czasu na dyskusję, która powinna być istotnym elementem doskonalenia modelu dydaktyki i jego realizacji.

W pracach Komisji Dydaktycznej Polskiego Towarzystwa Historycznego, której posiedzenia odbywają się 2-3 razy do roku i skupiają dydaktyków uniwersyteckich oraz nauczycieli, staramy się pozostawić sporo czasu na dyskusję, albowiem doświadczenie i refleksje uczestników spotkań są nie do przecenienia. Zajmowaliśmy się standaryzacją, Krajowymi Ramami Kwalifikacji, systemem egzaminacyjnym, wprowadzeniem przedmiotu historia i społeczeństwo.

Aby zamknąć swą wypowiedź, posłużę się także cytatem. Profesor Aleksander Gieysztor w artykule opublikowanym w osiemdziesięciolecie urodzin prof. Stanisława Lorentza pisze: „Lorentz jest człowiekiem któremu się chce. I dalej rozpatruje tę gotowość działania w kategoriach wiary, nadziei i miłości”. Sądzę, że te trzy cnoty, zwane kardynalnymi, powinny nami kierować w działaniach dydaktycznych. Niezbędna jest wiara w trafnie sformułowane cele, nadzieja na ich realizację, a powinno to odbywać się $\mathrm{w}$ atmosferze przyjaznego patrzenia na otoczenie, co jest niezbywalną dys- 
pozycją nauczyciela. Nauczyciele muszą też mieć chęć działania, jak Grażyna Pańko, szefowa Zakładu Dydaktyki Historii i Wiedzy o Społeczeństwie, którego jubileusz dziś obchodzimy, oraz wiele innych osób, wśród których można wymienić wielce zasłużonego emeryta (formalnie) wśród dydaktyków, dzisiejszego uczestnika dyskusji, Profesora Adama Suchońskiego. Ad multos annos.

\section{Bogumiła Burda (Uniwersytet Zielonogórski)}

Zacznę od kilku przykładów, w jaki sposób można zadbać o naszą dydaktykę historii.

Jestem nowożytnikiem i dydaktykiem historii. Prowadząc swoich doktorantów, ukierunkowuję ich tak, by i oni mogli zdobywać specjalizację z zakresu dydaktyki historii. W nowej strukturze habilitacji i profesury będzie można zgłaszać do Centralnej Komisji do Spraw Stopni i Tytułów Naukowych i proponować taką Radę Wydziału, w której są specjaliści z zakresu dydaktyki historii. To istotny element naszego zaplecza. To ważne, że odbywają się cykliczne konferencje dydaktyczne w Toruniu czy we Wrocławiu.

W ramach swoich zajęć dla studentów jeden wykład poświęcam, tak jak my dzisiaj, stanowi dzisiejszemu i perspektywom dydaktyki historii, by każdy absolwent coś na ten temat wiedział.

Jeśli chodzi o kształcenie nauczycieli, od wielu lat uważam, że studia nauczycielskie, tak jak i medyczne, powinno odbywać się w jednym cyklu, bez przechodzenia na inną uczelnię czy kierunek po ukończeniu pierwszego stopnia. Kandydat na nauczyciela powinien być przyzwyczajany do kształcenia umiejętności pracy z uczniem i dawania mu możliwości zdobywania wiedzy, nie tylko w oparciu o podręcznik, który zresztą ma różną formę (i różną objętość) w różnych krajach - np. podręczniki amerykańskie, których badaniem ostatnio się zajmuję, potrafią liczyć ponad 1000 stron.

Co do praktyk pedagogicznych, to ostatnie rozporządzenie w sprawie standardów kształcenia nauczycieli zwiększa liczbę godzin praktyki zawodowej. W praktyce dzielimy ją na praktykę ciągłą, we wrześniu, oraz tzw. śródroczną, w trakcie roku szkolnego. 
Uczestniczę w projekcie sześciu państw europejskich - Francji, Portugalii, Finlandii, Rosji, Węgier i Polski - dotyczącym trudnych problemów w historii: np. kolonializmu, kolaboracji itp. Problemy w kształceniu nauczycieli i przekazywaniu tych treści uczniom są takie same w tych wszystkich krajach. Merytoryczne i pedagogiczne przygotowanie nauczycieli jest tam częściowo spójne. Ale wymaga ono też spojrzenia z perspektywy konkretnego systemu edukacji. Specyfiką np. Polski jest dążenie, by wszyscy mieli ukończone studia. Z kolei zgodnie z wymogami awansu zawodowego nauczycieli konieczne jest przygotowanie do nauczania drugiego przedmiotu - to też rzutuje na strukturę kształcenia i skłania nauczycieli do dokształcania się. Dydaktycy historii są na to otwarci.

Nie należy przy tym zapominać o tym, że dydaktyka historii to nie tylko przygotowanie nauczycieli, ale także metodologia badań naukowych, poznawanie i sprawdzanie kształcenia.

\section{Danuta Konieczka-Śliwińska (Uniwersytet Adama Mickiewicza w Poznaniu)}

Pojęcie dydaktyki historii jest na tyle szerokie, że mieści w sobie takie zagadnienia, o których dzisiaj mówimy, jak np. szkolna i pozaszkolna edukacja historyczna, łącząc je z odpowiedzią na pytania, czego uczymy, po co i jak. W pojęciu dydaktyki historii mieści się również koncepcja kształcenia nauczycieli (w Polsce, w perspektywie porównawczej - europejskiej czy światowej) i odpowiedź na pytanie: jak powinniśmy uczyć? Według jakich pomysłów? Jakiego nauczyciela chcielibyśmy wykształcić?

W swojej wypowiedzi chciałabym zwrócić uwagę na inny aspekt dyskusji o współczesnej dydaktyce historii, o czym do tej pory jeszcze nie mówiliśmy, mianowicie na środowisko dydaktyczne. W moim przekonaniu najlepsze efekty uzyskamy wówczas, gdy to środowisko będzie realnie funkcjonowało i współpracowało ze sobą, będzie w dobrej kondycji naukowej i badawczej, będzie generować ciekawe pomysły, będzie w stanie także spełniać funkcję krytycznego konsultanta czy krytycznego partnera do rozmów o tym, jak edukacja historyczna w szkole powinna wyglądać, jak powinniśmy kształcić nauczycieli. 
Problem polskiego środowiska dydaktycznego można, moim zdaniem, rozpatrywać w trzech aspektach (wymiarach).

1. Aspekt historyczny. Mamy za sobą wspaniałą przeszłość dydaktyki historii w Polsce z ogromnym wkładem wielu ośrodków naukowych, dorobkiem i osiągnięciami. Ważne jest, byśmy to dziedzictwo, tę historię zachowali. Spotykamy się dzisiaj z okazji czterdziestolecia Zakładu Dydaktyki Historii we Wrocławiu. Istotne jest, byśmy wiedzieli, co się wydarzyło nie tylko tu, ale także w innych ośrodkach, zakładach dydaktyk. Niestety, nie ma opracowanej całościowej i szczegółowej historii dydaktyki historii w Polsce. Znamy ją często z własnych doświadczeń, ale mamy kłopot ze skonstruowaniem krótkiej, spójnej prezentacji tego, co się w tej dziedzinie zdarzyło. A jest to szczególnie istotne, jeśli mamy określić, ku czemu zmierzamy, odpowiedź na pytanie „co było?” jest w tym przypadku kluczowa dla dalszej refleksji.

2. Drugi ważny aspekt to teraźniejszość dydaktyki historii w Polsce. Kondycja współczesnej dydaktyki historii jest uwarunkowana m.in. kondycją zakładów dydaktyki historii w poszczególnych ośrodkach. Jeśli przypatrzymy się sytuacji w skali ogólnopolskiej, zauważymy, że w wielu ośrodkach nie ma już zakładów dydaktyki historii, ponieważ zostały one pochłonięte przez struktury wydziałowe (m.in. w Olsztynie, Białymstoku, Szczecinie). Można niemalże na palcach jednej ręki policzyć te ośrodki, które mają wyodrębnione zakłady dydaktyki historii, noszące właśnie taką nazwę. Bardzo często jest bowiem tak - i to jest kolejna tendencja, o której wadach i zaletach możemy dyskutować - że zmienia się nazwy tych zakładów, szukając zupełnie nowych koncepcji tego, czym ten zakład ma się zajmować (pojawiają się m.in. zakłady edukacji historycznej, dziedzictwa kulturowego, kultury historycznej itd.) Sama dydaktyka historii znika w tym kontekście z nazewnictwa jednostek instytutowych/ /wydziałowych.

3. Trzeci aspekt, niezmiernie ważny z punktu widzenia naszej dyskusji o perspektywie rozwoju, o tym, co powinniśmy robić, aby tworzyć i rozwijać środowisko dydaktyczno-historyczne w Polsce, to problem naszej przyszłości w strukturach uczelnianych. Bardzo często 
jest tak, że kiedy są zgłaszane pomysły włączenia dydaktyki historii w ogólnouczelniane struktury kształcenia nauczycieli, używa się argumentu ponadprzedmiotowego przygotowania kandydatów do zawodu nauczycielskiego (w myśl zasady: kształcony przez nas nauczyciel historii to taki sam nauczyciel jak nauczyciel fizyki czy matematyki). Chyba jednak nie! Musimy sobie odpowiedzieć na pytanie, kogo my chcemy kształcić: nauczyciela, np. szkoły podstawowej, gimnazjum czy szkoły ponadgimnazjalnej, który będzie uczył także historii, czy też nauczyciela historii, który od samego początku odebrał gruntowne wykształcenie merytoryczne i będzie pracował w szkole, koncentrując się nie tyle na badaniach naukowych, co na edukacji szkolnej? Odrywanie dydaktyki historii od instytutów historii jest w moim przekonaniu bardzo krótkowzrocznym działaniem i powoduje, że nauczycieli historii mogą kształcić nie historycy, tylko dydaktycy ogólni, pedagodzy. Stąd ważny postulat dla naszego środowiska - zadbanie o to, byśmy byli w strukturach uczelni, by zakłady dydaktyk historii realnie funkcjonowały. A żeby tak się działo, muszą być prowadzone badania dydaktyczno-historyczne - to, o czym mówiła Profesor Joanna Wojdon - dobrze byłoby, gdybyśmy ponownie podjęli różne kierunki wspólnych badań, m.in. w ramach prac na stopień, spotkań naukowych, komisji, konferencji naukowych. Jeśli coraz mniej będzie osób, które badawczo zajmują się dydaktyką historii, a nie tylko prowadzą zajęcia z dydaktyki historii od czasu do czasu, przy okazji swoich głównych zainteresowań naukowych, to kondycja dydaktyki historii w Polsce będzie coraz słabsza.

\section{Jacek Piotrowski (Uniwersytet Wrocławski)}

Zacząłem zastanawiać się nad potencjalnymi polami badawczymi. Jak słusznie tu Koleżanka Wojdon zauważyła, często koncentrujemy się na analizie środków dydaktycznych, najczęściej podręczników, i zawężamy pole naszych poszukiwań badawczych. Seniorka naszego środowiska, Pani Zofia Kozłowska, zaznaczyła przed chwilą, że żyjemy w czasach, kiedy świat bar- 
dzo szybko się zmienia, co warunkuje także przedmiot naszych zainteresowań badawczych. Jednym z takich współczesnych uwarunkowań edukacji jest niż demograficzny, nie tylko w Polsce, ale i w Europie. Jak wpływa on na edukację? Z mass mediów słyszymy co rusz o tym, że udało się uratować jaką́s szkołę w Polsce, bo powołano fundację, która przejęła zarząd nad tą szkołą. Zastanawiam się nad długofalowymi skutkami tego zjawiska. Czy fundacje będą w stanie zarządzać taką szkołą z bardzo skromnych środków pochodzących z subwencji oświatowej? Jak będzie wyglądała sprawa płac dla zatrudnionych tam nauczycieli? Z rozmów ze studentami studiów zaocznych wiem, że bywają już w Polsce szkoły, w których liczba zatrudnionych nauczycieli i administracji jest większa niż liczba uczniów. W związu z tym dojdzie do zróżnicowania środowiska nauczycielskiego. Będą szkoły w gminach bogatych o dużej liczbie uczniów, gdzie świadczenia dla nauczycieli będą takie, jak gwarantuje Karta Nauczyciela. Ale będą też szkoły na prowincji, zarządzane przez fundacje, $w$ których płace będą bardzo niskie. Dopóki będą tam przez kilka lat jeszcze pracowali nauczyciele, którzy byli tam zatrudnieni od zawsze, sytuacja zasadniczo się nie zmieni. Kiedy jednak ci nauczyciele odejdą na emeryturę, powstanie selekcja negatywna. Do tych szkół trafią te osoby, które nie znalazły zatrudnienia w większych ośrodkach. Jeżeli ideą całej reformy było wyrównanie szans edukacyjnych na poziomie gimnazjum, to może się okazać, że te różnice powstaną już na poziomie niższym, w szkole podstawowej. Naszym zadaniem jest monitorować sytuację, dokonać pewnej analizy przez badania, jak działają te fundacje.

Inny obszar: wszyscy obserwujemy postępującą informatyzację świata. Kiedy wchodzi się do gimnazjum, widać, że niemal połowa uczniów jest wyposażona w tablety i całe przerwy spędzają przy tym sprzęcie. Ba, grają ze sobą, stojąc przy przeciwnych oknach. Ale nie rozmawiają ze sobą. Nie ma kontaktu. Jeżeli szkoła ma być miejscem socjalizacji, wychowania, a uczniowie mają potem odnaleźć się w świecie, rozmawiać z drugim człowiekiem, to konieczna jest nasza refleksja na temat tego, jakie powinniśmy promować metody nauczania. Gdy zaczynałem pracę w zakładzie dydaktyki, Profesor Grażyna Pańko prowadziła nas do szkoły na zajęcia prowadzone metodą dramy. Pani Maria Maj-Majewska, nauczycielka, potrafiła zaangażować w nie uczniów. Zajęcia pozwalały zarówno na zabawę, jak 
i przekazanie konkretnych treści. Projekt upadł, bo wymagał ogromnego wysiłku od nauczyciela. Takich przykładów jest oczywiście znacznie więcej. Można mówić o grach planszowych, o kartach. Ale trzeba to promować. Biorąc pod uwagę spadek cen na rynku sprzętu elektronicznego, w ciągu kilku lat wszystkie dzieci będą wyposażone w tego rodzaju gadżety i zachęcanie ich dodatkowo na lekcjach historii, by się nimi posługiwali, mija się chyba z celem. Powinniśmy brać to pod uwagę, konstruując plany badawcze i dydaktyczne.

Pozwolę sobie nie zgodzić się z Panem Profesorem Suchońskim, który dość lekceważąco odniósł się do osób protestujących przeciw reformie edukacji historycznej. Otóż byłem na zjeździe założycielskim Obywatelskiej Komisji Edukacji Narodowej w Krakowie na Uniwersytecie Jagiellońskim w maju 2012 r. Spotkali się tam ludzie z różnych ośrodków akademickich, ale z inicjatywy tych, którzy głodowali w kilku kościołach krakowskich. Wydaje mi się, że nie można negować ich postawy i inicjatywy. Zwrócili oni bowiem uwagę na realne problemy i konsekwencje wynikające z wprowadzenia reformy. Na przykład na to, że w liceum dzieci (młodzież) będą musiały podejmować bardzo istotne decyzje ważące na ich życiu. Warto byłoby tę decyzję odłożyć chociaż o rok. W mediach wszyscy nieomal publicyści ubolewają nad tym, że wiedza o powstaniu styczniowym jest marna. A przecież po wejściu w życie reformy młodzież po raz ostatni spotka się z powstaniem styczniowym - jeśli nie będzie potem realizowała bloku „wojna i wojskowość” - w trzeciej klasie gimnazjum. Problemów tych nie można więc lekceważyć. A to, że osoby spoza naszego kręgu, spoza dydaktyków, angażują się, interesują i walczą wręcz o to, by przeprowadzić pewne zmiany, to cenna kwestia, która jest warta zbadania, opisania, analizy, także badawczej.

Wreszcie, jeśli chodzi o recenzje podręczników szkolnych, mogę podzielić się własnym doświadczeniem z jednym z podręczników firmowanych przez Centrum Edukacji Obywatelskiej, który zamieścił publicystyczne stwierdzenie Jana Tpmasza Grossa z książki Sąsiedzi jako obiektywny opis sytuacji w Polsce podczas drugiej wojny światowej. Podzieliłem się swoimi krytycznymi uwagami na ten temat. Gdy podręcznik wszedł do użytku szkolnego, „dobijałem się” w ministerstwie o informację, na podstawie jakiej recenzji tak bezkrytycznie treści te zostały zaakceptowane. Niestety nie 
otrzymałem żadnej odpowiedzi. Nie ma u nas takiego obyczaju, by informować o recenzjach innych rzeczoznawców - co przyjmuję ze smutkiem.

\section{Adam Suchoński}

Problemów protestu w sprawie edukacji historycznej nie przedstawiałem w sposób kpiący. Chodziło mi o to, że protestujący nie bardzo wiedzieli, o co im chodzi. Rozmawiałem z młodymi ludźmi w Opolu, którzy przykuli się łańcuchami do słupa, zrobili sobie dyby i postawili tablicę: protestujemy przeciw rugowaniu historii ze szkół. Gdy im mówiłem, że historii się nie ruguje, to twierdzili, że jestem niezorientowany. Ci przykuwający się nie wiedzieli, o co chodzi. Biorę udział w dużym programie badawczym w Kilonii. Badamy kształtowanie się pojęcia "globalizm”. Okazuje się, że $70 \%$ biorących udziału w protestach przeciw globalizacji nie rozumie tego pojęcia.

\section{Zofia Kozłouska}

Inicjatorami zeszłorocznych protestów byli pracownicy Uniwersytetu Jagiellońskiego - uczelni, która z wymagań wstępnych na studia na kierunku historia wycofała wyniki egzaminu maturalnego $\mathrm{z}$ historii.

\section{Bogumiła Burda}

Zmiany podstawy programowej zostały przyjęte w 2008 r. Zaczęła być wprowadzana do szkół podstawowych i gimnazjów w 2009 r. Gdy więc protesty się zaczęły, było trzy lata za późno. Nie obrażając uczestników protestu, najpierw należało przestudiować dokument mówiący o wprowadzeniu reformy, a potem wyjaśniać pojęcia. I nie wtedy, gdy reforma była już od trzech lat w toku. 


\section{Jacek Piotrowski}

Zgadzam się, że środowiska akademickie obudziły się za późno i debatę należało rozpocząć przed 2009 r.

\section{Maciej Fic (Uniwersytet Śląki w Katowicach)}

Dydaktyka historii jako dyscyplina nie ma i nie będzie miała takiej pozycji, by być wysłuchaną i mieć realny wpływ na działania. Nawet w naszym własnym gronie są osoby, które nie mają przekonania, że rzeczywiście jest to dyscyplina akademicka. I pewnie wiele trzeba byłoby zrobić, żeby ten stan zmienić.

Jeżeli mówimy o nauczaniu historii na uczelniach wyższych i przygotowaniu do zawodu nauczyciela, to warto pamiętać o tym, że kłopot wiąże się z brakiem holizmu: żeby uczący innych przedmiotów mieli świadomość, że kształcą nauczyciela, a zatem by kształcili go w nieco inny sposób, kładąc nacisk na nieco inne elementy niż na zajęciach dla pozostałych studentów. Współpracy z kolegami z innych zakładów czy katedr rzeczywiście często brakuje. Trzeba także pamiętać o tym, że dopiero ostatnio studia trzeciego stopnia, czyli studia doktoranckie, wprowadziły taki przedmiot jak dydaktyka szkoły wyższej. Przedtem, jeśli ktoś sam nie skończył specjalności nauczycielskiej, nie miał własnej praktyki pedagogicznej, nie był w ogóle przygotowany do prowadzenia zajęć, nie miał poczucia, jak należy uczyć. Zdarzało się, że byli to wybitni naukowcy, ale słabi dydaktycy, którzy nie potrafili swoich treści przekazywać.

Trzecia sprawa: swoboda uczelni wyższych w budowie swoich programów nauczania, siatek godzin niesie z sobą pewne niebezpieczeństwo doboru takich treści, które są średnio potrzebne potencjalnemu nauczycielowi albo nie wspomagają go w elementach kluczowych dla nauczania dwóch przedmiotów. Wprowadza się np. dydaktykę wiedzy o społeczeństwie, ale brakuje w programie studiów treści merytorycznych, które podczas lekcji WOS nauczyciel powinien uczniom przekazać. Z kolei podział na studia I i II stopnia oraz swoboda wymiany między nimi może powodować, że na studiach II stopnia będziemy mieli absolwentów całkiem egzotycznych dla 
historyków kierunków, np. fizyki. I takiego studenta, jeśli miał przygotowanie pedagogiczne w zakresie nauczania fizyki, powinniśmy potrafić w ciagu dwóch lat przygotować do nauczania historii - to też jest pewien kłopot i wyzwanie, przed którym stoją dydaktycy i nie tylko oni. Zwłaszcza że często liczba osób wśród studentów, które nie ukończyły historii na studiach I stopnia, jest zbyt mała, by tworzyć z nich osobne grupy.

Kolejna sprawa tylko sygnalnie: nie uniknie się upolitycznienia edukacji historycznej. Natomiast trzeba próbować wypracowywać jakiś kompromis. I to jest kwestia, o której warto mówić głośno. Sami też mamy przecież swoje przekonania, sami stajemy się uczestnikami wydarzeń. Należy dążyć do kompromisu, zrozumienia dla argumentów przeciwnika. Również podręcznik nie powinien w żadnym wypadku opowiadać się po jednej stronie sporu. Wreszcie, rolą nauczycieli jest umiejętne, nieinstrumentalne korzystanie z dostępnych podręczników.

Gdy rozmawiamy o dydaktyce historii, musimy pamiętać, że w szkole często pojawiają się osoby, które kończą jedynie różnego rodzaju kursy kwalifikacyjne, bardzo często ponadprzedmiotowe, a dzisiejsza codzienność szkoły podstawowej to nauczyciel historii, który swe podstawowe kwalifikacje zdobył w innej dyscyplinie. Liczba godzin powoduje, że nie da się zatrudnić tam pełnoetatowego historyka. Najczęściej jest to polonista po studiach podyplomowych z historii. Musimy zatem mieć świadomość, że dydaktyka historii to nie tylko dydaktyka I czy II stopnia studiów, ale także np. studiów podyplomowych.

Częstotliwość reform edukacji jest problemem. Nie jest niedobry sam fakt, że lubimy zmieniać, ale to, że zmieniamy, nie sprawdzając, co poprzednio się udało, co było dobre, a co nie. Nie ma pełnych cykli zakończonych ewaluacją, wyróżnieniem silnych i słabych stron i zatrzymaniem tego, co zostało zidentyfikowane jako mocne strony, zaś przeznaczeniem do modyfikacji elementów słabych.

Wreszcie kwestia praktyk pedagogicznych w szkołach. Niepokojące i negatywne jest coraz częstsze zjawisko utrudniania studentom dostępu do szkół. Umożliwianie odbywania praktyk pedagogicznych nie jest ustawowym obowiązkiem, jest to li tylko dobra wola dyrekcji, wsparta sugestia do dyrektorów, by wspierali proces kształcenia nauczycieli. Przyczyny negatywnego stosunku do potencjalnych praktykantów są bardzo różne: obawa 
nauczycieli o własne miejsce pracy, niechęć dyrektorów, by ktoś patrzył na ich dobrze zagospodarowane podwórko, kwestie wizytatorów i inne jeszcze elementy. Trudno jednak mówić o dobrych praktykach do obserwowania, skoro szkoła traktuje przyjmowanie studenta jako sytuację przymusową.

\section{Ewa Skrzywanek (Wrocławskie Centrum Doskonalenia Nauczycieli)}

Po kolejnych reformach edukacji coraz mniej nauczycieli przychodzi do nas się doskonalić. Wprawdzie doskonalenie jest wymuszone rozporządzeniami w sprawie awansu zawodowego nauczycieli, ale po zdobyciu kolejnych stopni awansu brakuje tu kontynuacji. Na początku swojej pracy znałam niemal wszystkich nauczycieli historii we Wrocławiu. Dzisiaj nie znam, ponieważ rozporządzenie nie zachęca nauczycieli, by przychodzili do metodyka prosić o poradę czy obejrzenie lekcji - co kiedyś było normą. Jedynie mądrzy dyrektorzy szkół podsyłają swoich nauczycieli do metodyków, prosząc o wsparcie.

Problem częstotliwości reform nie jest tylko problemem Polski. Już w latach dziewięćdziesiątych brytyjscy koledzy życzyli nam, byśmy nie przechodzili reform z taką częstotliwością jak oni. Niestety ziścił się ten gorszy scenariusz. Reformy nie są przepracowane, poprzedzone analizami. Wydaje mi się, że reforma powinna zaczynać się od uczelni. To tutaj powinny rodzić się pomysły, wnioski oparte o badania - tak jak mówiła Pani Wojdon. Natomiast tak się nie dzieje. Nie ma nawet koncepcji takich badań. Jeśli wchodzą tablety do szkół, powinno się badać, jaki to ma wpływ na ucznia, na odbiór historii, na zapamiętywanie, na uczenie się.

Warto poruszyć kilka problemów:

1. Kanon historyczny: w podstawie programowej z lat osiemdziesiątych był kanon wydarzeń, dat. Uważam, że dla poczucia tradycji, ciaggłości, tożsamości narodu powinien taki kanon istnieć.

2. Historia narodowa czy powszechna: w porównaniu do swoich kolegów z innych krajów nasza młodzież uczy się stosunkowo dużo historii światowej - to widać np. podczas spotkań młodzieży z różnych krajów. Młodzi ludzie z zagranicy zwykle są zadziwieni wiedzą 
naszych uczniów i pytają ich: po co wam to wszystko? Zaczynam się bać, że jeśli będziemy przeładowywać nasze podręczniki treściami z dziejów powszechnych, to zarysowując to szerokie tło, odciągniemy uczniów od spraw najistotniejszych. A dzisiaj młodzież nie tylko mało uczy się historii, ale jeszcze mniej uczy się jej z podręcznika. Zupełnie też nie korzysta z płyt multimedialnych dołączanych do podręczników ani z notatek.

3. Zmienia się społeczeństwo. Potrzebne są badania nad tymi zmianami, prowadzone niekoniecznie przez samych dydaktyków, ale także socjologów, psychologów. Warto pochylić się np. nad rodzicami naszych uczniów i ich stosunkiem do obowiązków szkolnych dzieci. Sama musiałam długo przekonywać rodziców dzieci w swojej szkole do zakupu atlasów historycznych - nie widzieli bowiem potrzeby ich stosowania (skoro mapy są w podręczniku). Rodzice wcale nie wstydzą się, że dzieci nie mają odrobionych zadań domowych uważają, że wszystkiego powinny nauczyć się w szkole.

4. Problemem jest też system edukacji - nie tylko w naszym kraju. Być może model $6+6$ byłby lepszym rozwiązaniem. Myślę, że gdy skończy się finansowanie ze środków unijnych tej reformy, wejdzie kolejna. Mam nadzieję, że my, historycy, przygotujemy się do niej. Uważam, że już powinniśmy mieć w szufladach nowe programy nauczania historii, by z nimi wyjść, gdy reforma będzie wprowadzana.

5. Jeśli chodzi o konferencje międzynarodowe - uważam, że takie problemy jak kolonializm czy postkolonializm to raczej problemy Europy Zachodniej. Dlaczego nie robimy konferencji międzynarodowych, pokazujących Europie Zachodniej nasze problemy, naprawdę istotne, i nasz punkt widzenia?

\section{Adam Suchoński}

Ale Zachód nie uznaje naszego punktu widzenia. 


\section{Joanna Wojdon}

Bo nie pokazujemy im go.

\section{Ewa Skrzywanek}

Zaniedbujemy okazję do prezentowania naszego punktu widzenia i np. przy obalaniu komunizmu w podręcznikach zachodnich dominuje upadek muru berlińskiego, a nie Solidarność. To zaniedbanie polskich historyków. Dydaktycy historii mają większą niż my, szarzy nauczyciele, siłę przebicia i też powinni podjąć to wyzwanie.

Chciałabym jeszcze krótko odnieść się do jednej kwestii: polityka historyczna jest, była i będzie. Historia zawsze była wykorzystywana dla różnych celów. Ważne, by nie została zawłaszczona przez jedną opcję polityczną.

\section{Izabela Koziej, dyrektor IX LO we Wrocławiu}

Słuchałam Państwa z różnych perspektyw: z punktu widzenia historyka, dydaktyka, ale także dyrektora szkoły, który rozmawia z kandydatem do zawodu. Nauczycielowi zawsze było trudno - jak cytowała prof. Kieniewicza Zofia Kozłowska. I nigdy nie będzie łatwiej. Nauczyciel to szczególny zawód. Historii najłatwiej uczyło się paradoksalnie w latach osiemdziesiątych, gdy był wróg, a młodzież była bardzo chętna. Dzisiaj młodzież jest inna, nie zła, ale inna. I trzeba to wziąć pod uwagę.

Jakie zadania my stawiamy przed przyszłymi nauczycielami i przed zakładami dydaktyki historii? Punkt ciężkości położyłabym na edukacji przez praktykę. Najważniejsze jest dzielenie się własnym warsztatem. Sami wiemy, że jeśli podpatrzymy dobry warsztat mistrza, to będziemy w stanie dopasować do niego całą resztę. To praktyka czyni z absolwenta studiów pedagogicznych prawdziwego nauczyciela.

Dwuprzedmiotowość nauczycieli jest dziś koniecznością - przy kurczeniu się liczby klas, godzin dla nauczycieli, funduszy. Każdy zarządzający edukacją, na dowolnym poziomie, musi śledzić sytuację demograficzną 
i brać ją pod uwagę - również uczelnie kształcące nauczycieli. Pocieszające, że w 2016 r. w szkołach zacznie się wyż demograficzny.

\section{Joanna Wojdon}

Poruszyliśmy w tej dyskusji wiele istotnych kwestii, dotyczących zarówno naszego środowiska - potrzeby jego zachowania, wzmocnienia, ale także zbadania i opisania - jak i dydaktyki historii jako dyscypliny naukowej, lokującej się między historią a pedagogiką, i jako systemu kształcenia nauczycieli, ze szczególnym podkreśleniem ich dwuprzedmiotowości, roli praktyk zawodowych i dostrzeżeniem pojawiającej się na nowo dydaktyki szkoły wyższej. Odnieśliśmy się także do szerszych problemów edukacji historycznej w Polsce, jej struktury w systemie edukacji w ogóle, podstawy programowej, a zwłaszcza do relacji między polityką a edukacją historyczną, z podkreśleniem konieczności dążenia do autonomii tej ostatniej. Dotknęliśmy różnych wymiarów naszej obecności w Europie i na świecie - nie zawsze satysfakcjonującej. Mam nadzieję, że zaproponowane tematy badań i propozycje praktycznych kroków zmierzających do wzmocnienia naszej dyscypliny pozwolą wytyczyć kierunki jej rozwoju na najbliższe lata. Szkoda, że z braku czasu wiele spraw zostało jedynie zasygnalizowanych, że zabrakło bardziej dogłębnej wymiany myśli i poglądów. Jestem jednak przekonana, że to nie koniec debat o dydaktyce historii. Zapraszając wszystkich polskich dydaktyków do Wrocławia na doroczny zjazd Międzynarodowego Stowarzyszenia Dydaktyki Historii w 2014 r., obiecuję zadbać, by w programie obrad dyskusja zajęła należne miejsce. 